Natural Resource Contests and Precolonial Institutions in Papua New Guinea

SHAUN LARCOM ${ }^{1}$

\footnotetext{
${ }^{1}$ Department of Land Economy, University of Cambridge, 19 Silver St Cambridge, CB3 9EP, United Kingdom. Email: st125@cam.ac.uk. I would like to thank participants at the State, Society and Governance in Melanesia Program Seminar Series at the Australian National University and four anonymous referees for their helpful comments.
} 


\title{
Natural Resource Contests and Precolonial Institutions in Papua New Guinea
}

\begin{abstract}
This article investigates the role that precolonial institutions play in relation to postcolonial natural resource ownership contests. Papua New Guinea provides a unique case study as it is recorded as having the most decentralized precolonial political institutions of any post colonial state. After an examination of its precolonial institutions, colonial land policy, and three case studies, it is concluded that persistent highly decentralized customary political units coupled with customary notions inalienability of land, and overlaid with a state property rights regime, leads to resource contests. It is concluded that resource ownership contests can have serious adverse consequences for resource management and that they are not easily overcome.
\end{abstract}

Keywords: Natural Resource Contests, Legal Pluralism, Precolonial Institutions, Resource Conservation. 


\section{INTRODUCTION}

In responding to the Commission of Inquiry into Special Agriculture and Business Leases (released in June 2013), the Prime Minister of Papua New Guinea, the Hon. Peter Peter O' Neill, said:

We will no longer watch on as foreign owned companies come in and con our landowners, chop down our forests and then take the proceeds offshore... For too long,

landowners have been taken advantage of and had their land stolen from under them. ${ }^{2}$

While it is true that many customary landholders have fallen victim to predatory companies and corrupt government officials, there is also a long tradition of customary landholders forcefully asserting their traditional property rights over those who hold state property rights over the same piece of land or natural resource, leading to protracted (and sometimes violent) ownership contests. These contests have had significant consequences; they have led to the abandonment of one of the world's largest copper mines during its peak production phase, reduced investment in agricultural projects, resulted in the harassment and eviction of small scale indigenous farmers, and seen eviction and compensation demands directed toward the state for the placement of its schools and other infrastructure (see Filer 1991, Koczberski and Curry 2004, Larcom 2013, Shepherd 1981,Waiko and Jiregari 1982, and Standish 2001). This article investigates the underlying causes of these contests, by focusing on the role Papua New Guinea's precolonial institutions play, and the consequences of these contests in terms of resource management and conservation.

While there are many beneficial aspects to Papua New Guinea's non-state institutions, it is suggested that there are two inter-related attributes that make them prone to generating

\footnotetext{
${ }^{2}$ The Chair of the Commission released his report in June 2013. The press release in response is undated.
} 
natural resource ownership contests; these are highly decentralized political authority structures and notions concerning the inalienability of land. ${ }^{3}$ It is proposed that these two attributes are particularly problematic when they interact with state institutions concerning the use and sale of land and natural resources.

It is hypothesized that decentralized political institutions have important implications for group decision making that can generate conflict and ownership contests. First, important decisions require consensus among the group as there is no central authority that is able to enforce a majority decision by containing the objections of dissenters. If a consensus decision cannot be reached, those who object can continue to do so; leading either to a stalemate or internal conflict, which if significant enough, could threaten existence of the group itself. Indeed, with weak central authority to enforce the decisions of the majority, there is little stopping some members reneging on a deal they previously agreed on; other than through the use of force. Likewise, with no (or weak) central authority to adjudicate and enforce decisions, those who consider themselves wronged and wish to have their grievances heard have few other options other than to engage in 'self help' or simply break away from the political unit and 'go it alone'.

In terms of the inalienability of land, if ownership cannot be transferred outside of the political unit that claims ownership to it, its sale or even long-term lease is difficult. Indeed, even if one generation may have formed a consensus over the sale or long-term lease of a tract of land, future generations may not abide by this decision due to a belief in its inalienability, and seek to take the land back forcefully. Indeed, notions of inalienability

\footnotetext{
${ }^{3}$ Decentralized political authority is defined as where power is dispersed within a small political unit and where there is an absence of central authority linking smaller units to larger political units. Inalienability of land refers to a situation where ownership cannot be transferred, especially to those outside of the political unit that claims ownership.
} 
coupled with no (or weak) central authority mean that it is difficult to enforce previous decisions made by the group in question. It also means that permanent transfers from one group to another (or a company or individual holding state title) will ultimately depend upon relative degree of strength (or force used) by the disputants.

Papua New Guinea is chosen as the subject for this investigation for two main reasons. First, its precolonial institutions are recorded to be the most decentralized of any country in the world (Müller et al. 2000). Second, it is unusually abundant in natural resources: with a land mass of 464,000 square kilometres, it has some of the most biologically diverse forests in the world and contains large reserves of non-renewable resources (Laurance et al. 2012). Natural resource exports (gold, oil, gas, copper, silver, and timber) are the major source of its earned income and the World Bank (2015a) estimates that the full production phase of a new large natural gas extraction project (PNG-LNG) that commenced in 2015 has the potential to increase GDP growth by 20 per. This could see it fill the gap left by the forced closure of the Panguna Copper mine in 1989 due to the Bougainville Crisis (see discussion below).

The remainder of this article is as follows. First there is a brief overview of Papua New Guinea, including its pre-colonial, colonial and post-colonial history. This is followed by a discussion of its precolonial institutions. Then, to understand the role of the colonial regimes on current outcomes, there is an overview colonial policy and practices in relation to land tenure. This is followed by an investigation into the role that precolonial institutions play in relation to resource contests by focusing on three specific cases; land-settlement schemes, the lease-leaseback scheme, and the closure of the Panguna mine. After a discussion of the findings the article concludes.

\section{PAPUA NEW GUINEA}


Using genetic data, Ahlerup and Olsson (2012) estimate that there has been approximately 65,000 years of uninterrupted human settlement on the island of New Guinea, making it one of the oldest outside Africa. This estimate also broadly accords with archeological and linguistic assessments. ${ }^{4}$ The Island of New Guinea was first settled from the north by diverse groups now categorized as 'Papuans', with subsequent waves of migration since, most notably by the Austronesian peoples. ${ }^{5}$ They are estimated to have arrived around 3,000-5,000 years ago, with many heading further east to settle Polynesia. ${ }^{6}$

From analysis of language (Mihalic 1989) and agricultural techniques (Zhang et al. 2004) there is evidence of extensive contact between the populations of different islands in the New Guinea region prior to European contact. In terms of agricultural production, while generalisations are difficult given the diversity of land, landscape, soil and climate; the practice of shifting cultivation was widely practiced, where a tract of land would be cultivated for a fixed period and then left to re-vegetate. Sweet potato was already the dominant agricultural crop of the densely populated central highlands when it was first discovered by Europeans in the early 1900s, while in other areas taro, yams, and sago were widely grown (Kambuou 1996 and Roullier et al. 2013). In terms of living standards, Connell $(1978,46)$ describes the people of precolonial Bougainville as living in 'subsistence affluence' where they were able to produce adequate food for consumption with a 'surplus

\footnotetext{
${ }^{4}$ Summerhayes et al (2010) found physical evidence of human settlement to almost 50,000 years ago. See Matsuda (2012) for a synthesis of the linguistic and archaeological evidence.

${ }^{5}$ There is considerable linguistic and cultural heterogeneity among Papuan peoples. For instance, compared to the one Austronesian language family there are 27 non-Austronesian language families spoken in Papua New Guinea (Lewis et al 2014).

${ }^{6}$ See Fischer (2002), Kirch (1997), and Matsuda (2012) for discussions on the history and migrations of the South Pacific.
} 
for entertainment'. This assessment is also consistent with first records of the German colonial administration in $1886-87^{7}$

The island of New Guinea was sighted and named by Portuguese and Spanish sailors in the $16^{\text {th }}$ century, however it was not until the late $19^{\text {th }}$ Century that what now makes Papua New Guinea was explored and colonised by Europeans. Papua New Guinea was first colonised following an agreement between Britain and Germany to partition the eastern half of the island of New Guinea in $1884 .{ }^{8}$ Britain declared the southern part a protectorate and named it British New Guinea, while Germany took the northern part (naming it Kaiser Wilhelmsland) and the New Guinea Islands. In 1906, the Australian Government was given control of British New Guinea and renamed it Papua. With the outbreak of the WW1, German New Guinea came under Australian military control following German surrender of the territory. In 1920, Australia received a mandate from the League of Nations for its government under trusteeship. Apart from a three year partial occupation by the Japanese army during the Second World War, the two territories remained under Australian control (which were effectively administered jointly from 1949) until independence in 1975. Today, Papua New Guinea is a parliamentary democracy with a population of approximately seven million people. However, the reach of the state is relatively weak and the vast majority

\footnotetext{
${ }^{7}$ The first annual report of the German Neu-Guinea Compagnie (Sack and Clark 1979, 20) that states:
}

The natives cultivate with care and industry the gardens and plantations in which they grow the fruit and vegetables which furnish sufficient food for their needs. But over and above their food requirements, which these gardens supply in abundance and without undue exertion, they at present have no needs and therefore no motivation to earn by labour the means to satisfy them.

\footnotetext{
${ }^{8}$ The western half of the island of New Guinea was officially claimed by Dutch 1828 . They left it largely alone until after World War II and administered it separately from the Dutch East Indies. In the 1960s, it was subsumed into Indonesia.
} 
of its citizens live on smallholdings tending semi-subsistence gardens and cash crops (MacWilliam 2013). Income per capita for 2012 is estimated to be $\$ 2,184$. Despite a period of recent strong economic growth that was largely fueled by higher commodity prices and a corresponding investment boom, approximately 40 per cent of the population lives in poverty. (World Bank 2015b).

\section{PRECOLONIAL INSTITUTIONS}

As stated earlier, Papua New Guinea is recorded as having the most decentralized precolonial political institutions of any country in the world (Müller et al. 2000). The underlying data used to make such an assessment is Murdock's (1969) Ethnographic Atlas. It contains quantitative measures for a range of institutional, economic, and social variables for 1270 cultural units across the world. He sourced his data from descriptions from anthropologists during 1890 to 1950 and explicitly aimed to exclude anything imposed by colonial regimes. What follows next is an overview of Papua New Guinea's precolonial institutions in terms of political centralization and land ownership, using Murdock's assessment as a reference point.

Murdock recorded 49 cultural units in what now makes up Papua New Guinea. For his measure of jurisdictional hierarchy, only 3 cultural units (the Trobriand, Purari, and Aua societies) are recorded as having one level of jurisdiction above the local level (e.g. petty chiefdoms). ${ }^{9}$ All of the other societies identified by Murdock are recorded as having no levels of jurisdiction above the local level, which is the lowest level of jurisdictional

\footnotetext{
${ }^{9}$ Each of these are island/coastal societies. The Trobriand and Aua languages belong to the Austronesia language grouping, while the Purari language belongs to the very different Papuan language grouping.
} 
hierarchy coded. This implies that power was shared within a village and that there was no designated village head (or 'chief').centralized ${ }^{10}$

There seems to be broad consensus among Papua New Guinea scholars that it was made up of thousands of small stateless and decentralized social units prior to colonization. Perhaps the most compelling evidence for this is that this is what was found at the time of European contact (see Jinks, Biskup, and Hank 1973, Lawrence 1969, Rowley 1958, and Strathern 1995). ${ }^{11}$ Indeed, Narokobi $(1996,28)$ considered that 'small self-contained communities' was the distinguishing factor of precolonial Melanesia compared to other places in the world. In terms of leadership and political structure, May $(2004,204)$, while acknowledging exceptions, concludes that Papua New Guinean societies were characterised as acephalous; 'lacking the formal, hereditary chiefly structures which typified neighbouring Polynesia and other small-scale traditional societies in much of Africa and Asia.'

Curiously, May (2004) also notes that during the postcolonial period there have been a number of claims to hereditary chieftaincy in areas where there is little or no anthropological evidence of the institution ever existing. There are various potential reasons for this phenomenon, including measurement error in the early accounts of anthropologists; they may have been blinkered by their own cultural biases or have been given false information by their informants. Alternatively, the result could be driven by some 'creative rewriting of

\footnotetext{
${ }^{10}$ Murdock records an absence of class divisions for more than half of the societies (62 per cent), with approximately one third having wealth distinctions. Four societies are recorded as having elite, dual or complex class systems (Buka, Trobriand, Mekeo, and Koita). Early accounts of the central highlands refer to the existence of 'big men' and 'rubbish men' (see Brandewie 1971 for a discussion).

${ }^{11}$ The Neu-Guinea Compagnie Annual Report 1886-87 (c.f. Sack and Clark 1979, 19) states: 'Larger communities under the centralized leadership of chiefs do not appear to exist. Up to this time only smaller settlements of a family type have been observed, which are not linked to each other and are frequently in a state of feud with each other.'
} 
traditional social structures' (May 2004, 232). Many of these claims have been made by elites within the postcolonial state. Whatever the reason for this phenomenon, it does cast some doubt on the early assessments that seems almost impossible to verify.

Another problem with measuring the degree of Papua New Guinea's precolonial political decentralization is that there are a number of data gaps. For instance, Murdock only has one value for the whole of Bougainville Island, which is an extremely diverse place itself. Lewis et al. (2014) report 22 distinct languages from three different language families spoken on the Island. The value recorded by Murdock is for the Siuai people who are situated at the southwestern tip of the island. Murdock records no level of jurisdictional hierarchy beyond the local community and no hereditary chiefs for this cultural unit. However, it is known that in other parts of Bougainville Island, chiefs and paramount chiefs currently enjoy considerable power and claim historical authority (Larcom 2013). Early reports by traders also document the existence of powerful paramount chiefs in precolonial times; most notably King Ghorai who asserted sovereignty over the Shortland Islands and the whole Bougainville Island in the decades before it was annexed by Germany in 1889 (see Knoll and Hiery 2010 and Oliver 1973 for primary accounts of King Ghorai). However, asserting power over an area and having power over an area two different things. While there are documented accounts of King Ghorai launching successful raids on Bougainvillean communities for defying his will, there is no indication that he ruled Bougainville in any practical sense. Murdock did not code specific rules relating to land and its transfer within generations, however Oliver (1973, 162-3) suggests there are five on Bougainville (see discussion below) and that have their origins in precolonial times. They are: different people own different property rights over the same piece of land (e.g. harvesting rights versus the ability to exchange ownership); the persons owning each set of rights tend to be multiple rather than individual; while some joint owners tend to exercise more decisive authority, disposal 
normally requires consensus; permanent rights over land can be exchanged under certain circumstances, but such exchanges are kept between kinfolk (unless through force); and unauthorized trespass is taken very seriously. While great care must be taken in extrapolating these rules across Papua New Guinea, they do give some indication of land tenure rules within a highly politically decentralized society. Indeed, the importance of the concept of inalienability of land and consensus decision making has been well documented in many other parts of Papua New Guinea (see Morauta, Pernetta, and Heaney 1982 and Nonggoorr 1993).

In summary, there seems to be little dispute that the vast bulk of precolonial Papua New Guinea was made up of small decentralized communities with few or no layers of jurisdictional hierarchy, where local leadership was largely competitive and dependent on personal qualities. ${ }^{12}$ Clan or family leaders or 'big men' (chosen for their personal attributes) usually shared power within a village (which was often a collection of hamlets) rather than a designated chief, and there was no level of jurisdiction (such as a paramount chief) above this level of authority. While there were individual land use rights, control rights were normally held collectively and land could not be permanently transferred to people outside one's own group.

\footnotetext{
${ }^{12}$ May $(2004,209)$ in noting both the exceptions and the anthropological debates surrounding Papua New Guineas precolonial institutions concludes that: traditional leadership in Papua New Guinea can be generally characterised as largely dependent on personal qualities...substantially constrained by competition, by specialisation of leadership roles, by the prevalence of communal modes of decision making, and by communal demands on leaders and resentment of leaders who attempt to raise themselves too far above other members of the society.
} 
The remainder of this article is focused on exploring the relationship between the precolonial institutions described above and current resource ownership contests, with a particular focus on the role that decentralized political authority and inalienability of land play. However, first there is an overview of colonial land policy. This overview is provided as customary institutions are unlikely to be static, and are likely to have been influenced by colonial policy and changes in economic circumstances. Furthermore, there is a wide body of literature across much of the postcolonial world that links current land and resource disputes to their colonial past.

\section{COLONIAL LAND POLICY}

From the beginning of Papua New Guinea's colonial experience both colonial powers expressed a desire to respect and protect customary land rights. In the case of British New Guinea this dates back to Commodore Erskine's proclamation announcing the Protectorate, promising that '[y]our lands will be secured to you' (c.f. Biskup, Jinks and Nelson 1968, 5), while the first annual report of the German Neu-Guinea Compagnie stated its right to acquire land free of charge that was 'not owned by the natives whose rights are to be respected' (Sack and Clark 1979, 13). While both colonial administrations did subsequently acquire tracts of land, they largely stuck to their promises. ${ }^{13}$ Biskup, Jinks and Nelson $(1968,100)$ report that

\footnotetext{
${ }^{13}$ As noted by MacWilliam $(1988,85)$ all colonial administrations (ie German, British, and Australian) had legislation in place to protect customary land rights. The 1888 Land Regulation Ordinance only allowed the acquisition of customary land if the Administrator was 'satisfied that it was not required or likely to be required by its customary owners' in British New Guinea. In German New Guinea regulations were brought in 1904 to explicitly exclude 'land under use' from acquisition. However, it is known that some villagers on the Gazelle Peninsula and those near Lae were displaced by the early colonial administration, and it is unlikely that these are the only cases. (Biskup, Jinks and Nelson 1968, 100). In terms of the early Australian administration, Hubert Murray (Lieutenant Governor of Papua from 1908 to 1940) is widely acknowledged to have to made considerable efforts to 'protect the Papuans in the possession of their lands' (Biskup, Jinks and Nelson 1968, 84).
} 
by 1936 over 900,000 acres of land were held by Europeans in New Guinea (the former German colony) and about 250,000 acres in Papua (the former British colony); which amounts to a little more than one per cent of the Papua New Guinean land mass.

Determining whether the land acquired by the colonial administrations was taken from customary owners is not straight forward. The administrations believed that there were large tracts of 'uninhabited' and 'unclaimed' land (Sack and Clark 1979, 13), that were often situated beyond the borders of different ethnic groups and which were deemed to be 'no man's land' (West 1968, 129) or 'wastelands which did not seem to be claimed by anybody' (Hasluck 1976, 114). However, some commentators such as Oliver (1973) have suggested that virtually all land had ownership claims upon it, even if it was sparsely populated. In terms of land acquired that was recognised to have customary ownership, and therefore purchased, colonial administrations had regulations in place to protect customary land owners that were for the most part tightly enforced. In this regard, MacWilliam $(1988,97)$ concludes that in relation to land for large scale coffee plantations in the highlands under the Australian administration '[s]trict procedures ...were enforced to cover purchase of land from indigenous holders'. Although Filer and Sekhran $(1998,30)$ suggest that the processes for land 'purchased' from customary landholders for plantations in German New Guinea were far less rigorous than that of later administrations.

The development path chosen by the Australian colonial administration in the post WWII period up until the mid-1960s focused on increasing the agricultural productivity of small scale farmers with the aim of '[s] ecuring village life' and to 'check the formation of a landless proletariat' (MacWilliam 2013, 11). ${ }^{14}$ This policy involved placing barriers, and

\footnotetext{
${ }^{14}$ Hasluck $(1976,126)$ stated that he 'inherited a basic policy of preserving the land for the indigenous people and limiting the alienation of land to what was required for necessary public purposes and economic
} 
even blocking, large scale enterprises that were deemed to threaten these aims. Hasluck (1976), the Australian minister responsible for the administration of Papua and New Guinea from 1951 to 1963 faced considerable pressure to 'free up' land by expatriate and indigenous growers (and some administration officials) for plantations and other commercial enterprises. Hasluck also had a desire to obtain land for the indigenous population who were already landless, endowed with poor quality agricultural land, or faced population pressures. He also held the belief that changing agricultural practices eventually required individual titling (including the need to use land as collateral for loans). Despite these pressures for large scale land reform, and his own beliefs in individual titling, he took a cautious approach. This caution was driven by both practical impediments and prudential foresight. For one, he realised that the colonial administration had a very limited understanding of how customary land rights operated, and few resources to undertake a proper investigation across Papua and New Guinea. ${ }^{15}$ From the 1950s he was already well aware of demands from customary land owners to be given back land that had been 'wrongly 'sold' to the Administration in former years' (Hasluck 1976, 116). ${ }^{16}$ In terms of prudential foresight, Hasluck $(1976,124)$ was also

development'. Hasluck $(1976,114)$ stated that he 'endorsed without question the long-established policy of protecting native land rights.'

${ }^{15}$ The slow progress made by the administration in registering customary land was a source of frustration to Hasluck (1976). Difficulties included few resources and the complexity of customary ownership regimes that varied geographically.

${ }^{16}$ Hasluck $(1976,116)$ concludes that these situations might have arisen due to a payment being made to 'a person who may not have had the right to sell the land'; he also concluded that:

'It was plain that these disputes or grievances over land already alienated had become more acute with the progress of agriculture and the movement into cash cropping. People were now coveting what they had previously disregarded.' 
of 'the belief that loss of land would breed animosity among future generations'. ${ }^{17}$ Indeed, in the period immediately preceding independence the colonial administration did attempt to roll out a voluntary individual titling scheme, however despite having very little uptake it did manage to fuel local land disputes and claims from customary owners whose land was sold during the early colonial regimes (Filer and Sekhran 1998).

As outlined by MacWilliam (2013), while the Australian colonial administration's uniform development policy was largely successful in raising living standards across Papua and New Guinea and keeping the vast majority of the population on the land, by the mid 1960s there were growing pressures to accelerate development that would have implications for land and resources policy. Independence was looming and there was pressure on the administration to secure an internal revenue base for a newly independent state. There were also strong internal pressures forcing change. While the vast majority of the population remained on their traditional customary lands, widespread small-scale cash-cropping had already led to greater individualization of land rights, and an emerging indigenous bourgeois that were beginning to harness state power for their own ends. In addition, the claims of those who were landless had intensified and who had taken to squatting on mainly largeholdings. Following the departure of Hasluck and the publication of an influential World Bank report in 1963, the administration broke with previous policy an embarked on an accelerated growth strategy, which included the establishment of agricultural nucleus estates and the Panguna copper-gold mine (discussed below).

In summary, customary ownership over land was mostly respected by Papua New Guinea's colonial administrations. A commonly cited figure is that that around 3 per cent of the total

\footnotetext{
${ }^{17}$ MacWilliam $(1988,86)$ estimates that even with the post war land rush in the eastern highlands only 90,000 hectares (approximately 222,000 acres) were alienated between 1953 and 1960 .
} 
land area in Papua New Guinea was 'alienated' during the colonial period (Morauta, Pernetta, and Heaney 1982) and large tracts were given up by the state following independence. What is currently under state or private control has been either leased, purchased, or was deemed to be uninhabited. In relation to land that was puchased, colonial authorities often went to considerable lengths to ensure that customary landholders freely and knowingly entered into permanent land transfers. In this regard, MacWilliam $(1988,80)$ considered that a 'principal object of state power over the last 100 years has been limiting the land which is held as centralized and concentrated private property'.18

\section{NATURAL RESOURCE CONTESTS}

What follows next is an analysis of how the remnants of Papua New Guinea's precolonial institutions can lead to contests over natural resources in the post-colonial state and the consequences of such contests in terms of resource management. The examples chosen are resource contests connected to the land-settlement schemes, the lease-leaseback scheme, and the closure of the Panguna copper and gold mine (perhaps the most traumatic event in Papua New Guinea's post-independence history). The key implications in terms of precolonial institutions are then outlined in the discussion section.

\section{Land-settlement schemes}

Land settlement schemes introduced by the Australian administration and supported by the post-colonial state were deemed to be beneficial for a number of reasons. For one, there were vastly different population densities and fertile land was distributed unevenly (Hasluck 1976). It was also believed that they provided 'a means of individualizing indigenous land tenure and promoting economic development' (Hulme 1982, 25). As noted by Hulme (1982), the

\footnotetext{
${ }^{18}$ In the postcolonial period, while there were early efforts by Papua New Guinea's new elite to further accumulate largeholdings, these mostly failed and smallholders were largely protected (MacWilliam 2013).
} 
colonial administration believed that customary land tenure was unsuited to perennial cash cropping, discouraged individual effort, and was unable to be used as collateral for loans to raise starting capital. In addition, he also suggested that the lack of clearly defined boundaries meant that customary land was more subject to ownership disputes.

While there were a number of small scale settler schemes previously (Hasluck 1976), the nucleus estate schemes of the 1960s and 70s (where smallholder blocks surrounded a large plantation estate) were the first to be comprehensively planned by the administration. This included careful planning in terms of choice of crop, scale, marketing, processing, infrastructure, and finance. Once suitable (previously alienated) land was found, blocks were advertised and prospective settlers were interviewed. Upon being selected, settlers were sold individual 99-year agricultural leases over blocks of around 5 hectares financed by the Papua New Guinea Development Bank.

The first nucleus estate oil palm scheme was near Hoskins in West New Britain in 1967. The settlers were primarily from the land short areas inhabited by the Tolais, Sepiks, and Chimbus; and community centres, schools, first-aid posts, market sites, government offices, church sites, and commercial lots were provided. For Hoskins, Hulme (1982) estimates that the economic rate of return was approximately 25 per cent per year and that 95 per cent of settlers had repaid their loans within 6 years. However, despite being a success in terms economic and agricultural returns, Hulme $(1982,34)$ reported that '[i]nter-ethnic fighting was a serious problem in the early years of the Hoskins scheme and a number of homicides occurred'. Another problem was that customary landholders surrounding the schemes were often left disadvantaged in terms of service provision and economic development. In an effort to counter such problems later schemes, such as the Popondetta scheme, aimed to 'assist the traditional landowners of the project area in establishing oil palm blocks on village land' 
(Hulme 1982, 34). ${ }^{19}$ However despite such efforts, villagers often persisted with large compensation claims on previously alienated land.

In a more recent review of the settler schemes in Hoskins and Popondetta, Koczberski and Curry $(2004,364)$ found that newer generations of customary landowners continue to contest the legitimacy of previous exchanges believing that they have been denied their 'birthrights'. They go on to document how subsequent generations see themselves as the rightful owners of the land and make eviction demands, compensation claims, or restrict the settlers' economic activity (including a prohibition on the replanting of non-productive palms), even after they had been 're-compensated' in some cases. ${ }^{20}$ These demands are made on the grounds that their ancestors were either not paid adequate compensation or did not have the authority to lease the land to outsiders.

\section{Lease-leaseback scheme}

The special agriculture and business lease-leaseback scheme (SABL or the 'lease-leaseback scheme') was developed by the post-colonial state in the late 1970s. It enables the state to lease land from its customary owners for up to 99 years and then lease it back to them, utilise itself, or lease it onto others. The main rationale for its introduction was that it provided a practical solution for customary landholders to utilize their land commercially by creating

\footnotetext{
${ }^{19}$ The promotion of 'village oil palm' has been a characteristic of all the major palm oil schemes in Papua New Guinea, regardless of whether they have resettled blockholders.

${ }^{20}$ Koczberski and Curry (2004:364) report that: landowners have imposed restrictions on the economic activities of LSS [land-settlement scheme] leaseholders on their blocks, and have vigorously opposed the replanting of senile oil palms by settlers. Leaseholders are prevented from establishing small businesses such as stores and poultry projects, and are discouraged from harvesting too much oil palm fruit because if their incomes are perceived to be high, they become targets for harassment and monetary demands.
} 
certainty of title which could then be used for collateral for loans (Numapo 2013).

Subsequently, a number of customary owners have also leased their land to third parties for payment.

Following widespread reports of dubious large-scale lease transfers and corrupt activities, the Papua New Guinean state established a Commission of Inquiry into the scheme which reported its findings in 2013. Chief Commissioner John Numapo (2013) found that more than five million hectares of land (approximately 11 percent of Papua New Guinea's landmass) had been leased to private entities under the scheme, most of which was over virgin tropical hardwood forests. Numapo (2013) found widespread corruption and incompetence of government officials; he also found that many of the agro-forestry projects, which were described as clearing land (and selling the timber) for agricultural projects, never moved beyond the selling of timber stage. Numapo $(2013,242)$ concluded that logging companies 'mislead and deceive landowners with the assistance of corrupt government officials... literally pay[ing] off assertive clan leaders and then use divide and rule tactics to obtain subleases'. As a consequence, Numapo recommended that the bulk of the leases he had been tasked with investigating should be revoked or voided. He also made a number of legislative recommendations, including limiting the lease period to 50 years and strengthening the ownership and informed consent verification procedures of the scheme.

While Numapo $(2013,242)$ highlights the presence multinational predatory logging companies 'take[ing] advantage of gullible landowners and desperate for cash clan leaders'; this is not the complete picture. Filer (2012) concluded that while there were numerous unscrupulous operators who showed little intention of developing the land for agriculture, some did and were thwarted by claims from customary landholders. He cites the case of a large bio-ethanol project that had been granted 99 year leases over two large tracts of land. Despite seemingly the best of intentions of its foreign owners, who established a 20 hectare 
project nursery, the project had been placed in a state of limbo due to disputes with customary owners and squatters who continue to occupy the land.

Closer investigation of the 17 leases that Numapo (2013) investigated shows that only three did not involve serious landowner disputes. Six of the leases involved land that was subject to pre-existing customary ownership disputes; while most involved disputes between different factions of customary landowners, with some agreeing with the lease arrangements and others not. While some disputes centred on a small group of customary landholders seeking to push through questionable leases with dubious companies without the knowledge or consent of the majority of landowners, others involved 'disputes and arguments between landowners' (Numapo 2013, 173); 'rival landowner company[ies]' (Numapo 2013, 98); 'irreconcilable positions between the two contending land owner groups' (Numapo 2013, 109); and 'going it alone' (Numapo 2013, 86). In terms of the latter, Chief Commissioner Numapo found two cases where opposition from a group of customary land owners surfaced after the proper processes were completed and leases signed (and in one case trees planted), who wished to divide the lease and engage a different project partner.

\section{The Closure of the Panguna Mine}

Perhaps the most prominent individual example of a natural resource contest relates to the forced closure of the Panguna open-cut copper and gold mine on Bougainville island in the late 1980s. The mine was opened in 1972 by Bougainville Copper Limited (BCL), a subsidiary of Rio Tinto and was one of the largest in the world. It had a capital expenditure of approximately \$US500 million dollars (in 1970 dollars) and a construction workforce of over 10,000 people. ${ }^{21}$ During its production phase it employed more than 3,000 people and provided almost 20 per cent of Papua New Guinea's entire annual internally generated

\footnotetext{
${ }^{21}$ Adjusting for inflation this would be over $\$ 3$ billion in 2016.
} 
income. $^{22}$ However, during peak production, a group of frustrated local landowners led by Francis Ona demanded billions of dollars in compensation from BCL. In May 1989, following bouts of sabotage the mine was closed and it has never reopened. ${ }^{23}$ The closure of the mine triggered the Bougainville Crisis that was effectively a separatist civil war followed by further fragmentation and fighting that spanned decade and cost many thousands of lives. ${ }^{24}$ It led to the destruction of most of the infrastructure on the island and the complete withdrawal of the Papua New Guinean state for a number of years.

The Panguna mine was carved out of Bougainville amidst the backdrop of growing land shortages, social differentiation, and class antagonisms brought about in part by widespread cash cropping, growth in the individual control of land, and population increases (see Lasslett 2012, 2014, Lasslett and Stańczak. 2014, Thompson 1991, Thompson and MacWilliam 1992, Regan 1998). ${ }^{25}$ During the lead-up to mining operations there was considerable public opposition and protest toward the proposed land acquisitions from indigenous landowners and expatriate planters (including the owner of the Arawa plantation). At the time, the Department of Territories (1969) was also made aware that monetary payments would be

\footnotetext{
${ }^{22}$ Thompson $(1991,81)$ estimated that in a full uninterrupted year of 1989, the mine would have contributed 30 per cent of total exports equal to Kina(K) 430 million, 11 per cent of total GDP equal to K315 million, 4000 direct jobs and 8000 indirect jobs, gross salary payments of K52 million, government revenues of K162 million and K22 million in employee income tax; 19 per cent of the national government's budget of K184 million and foreign exchange earnings of K200 million (in 1989, 1 Kina approximated US\$1.2).

${ }^{23}$ Ona and his followers then attempted to succeed from Papua New Guinea by establishing the kingdom of Me'ekamui.

${ }^{24}$ The number of people who died as a result of the crisis is not known with certainty: Hermkens (2007) puts the figure at around 15,000 (which is approximately 10 per cent of the population), while Larcom (2013) reports a figure of around 20,000.

${ }^{25}$ For some authors such as Thompson and MacWilliam (1992) class conflict is the central issue in understanding the Bougainville Crisis.
} 
insufficient to compensate indigenous land holders for the loss of their land and that resettlement would be very difficult. ${ }^{26}$ Despite these concerns, it was the view of the Australian government that individual rights would have to give way to the interests of the Territory as a whole. ${ }^{27}$

Given the sheer size of the mine and its supporting infrastructure (including the need to construct a port, a large scale electricity generation plant, and a worker accommodation town) the mine operators required a considerable amount of land. ${ }^{28}$ The mine site itself was sparsely inhabited and great lengths were taken to minimise disruption to local landowners in

\footnotetext{
${ }^{26}$ In a confidential note, David Hay (1969: 2) (the Administrator of the Territory of Papua and New Guinea) to Warwick Smith (the Secretary of the Department of External Territories) stated:
}

The Dapera people say that even if they get the other land to replace that which is going to be destroyed by the mine, what guarantee do they have of secure tenure? It belongs to other people and even though the Administration calls itself the owner, won't other people dispute that?

This highlights the difficulties the administration knew it faced in displacing indigenous landowners to secure land for the mine. It is also a frank acknowledgement of the existence of legal pluralism by the Administrator. ${ }^{27}$ In a letter to the President of the Planters' Association of New Guinea (in relation to the proposed acquisition of the Arawa plantation), John McEwen (1969:2) the then Acting Prime Minister of Australia stated:

The need to acquire land for a public purpose and in the public interest not infrequently occasions disturbances and inconvenience to the owners. This is regrettable but the loss of the plantation and other land required for this project needs to be viewed against the massive benefits in terms of income, employment and revenue which will be generated in the Territory as a whole from the development of this project.

${ }^{28}$ As outlined by Newman (1969), the BCL's parent company negotiated an initial tax free period on mining revenue and a guarantee from the administration to grant the necessary leases for its operations. The Mining (Bougainville Copper Agreement) Ordinance 1967 designated land required for the mining operation to be for a 'public purpose' (Section 12). If owners refused to sell land designated for a public purpose, the compulsory acquisition clause of the Land Ordinance 1962 could be triggered. 
choosing where to locate the supporting infrastructure. ${ }^{29}$ For instance, the mine operators chose Arawa (the site of colonial plantation) as the main site to house mine workers and their families to minimise disruption to local landowners, despite there being more suitable sites in terms of climate and proximity to the mine. Despite BCL's efforts some landowners (and entire communities) were required to relocate their residences and gardens. The residents were compensated in terms of lost property and income for the land that was acquired.

Needing land to build the port, some landowners refused to sell and the colonial administration forced the sale and police were called in to remove the customary land owners. (Oliver 1973)

The mine operators were compliant with the state property rights regime. In addition to following due process in acquiring mining rights and the land for the mine, BCL also paid royalties to the state and local landowners. ${ }^{30}$ Thompson $(1991,75)$ estimates that the landowners received K22 million in cash benefits derived from royalties over the period 1978-1987, plus an extra K1.2 million per year from the purchase of goods and services. ${ }^{31}$ While the royalties received by landholders were small in absolute terms, they were not insignificant in per capita terms. Thompson $(1991,75)$ reports that when mining began, there were approximately 2000 people in the various lease areas, suggesting that royalties per

\footnotetext{
${ }^{29}$ Thompson $(1991,75)$ reports that when mining began there were less than 500 people in the vicinity of the mine site and a total of 2000 in the various lease areas.

${ }^{30}$ Royalties paid were 20 per cent of the mine's proceeds. Of this 20 per cent, 18.75 remained with the central government and 1.25 per cent was paid to the North Solomons Provincial Government. Of this 1.25 per cent, 5 per cent was distributed to the customary land owners within the special mining lease area. Consistent with Australian law at the time, the colonial administration (and later the Papua New Guinean state) were the legal rights holders of the minerals.

${ }^{31}$ This compares to K919 million received by the National government, K75 million to the provincial government, K577 million to foreign shareholders; K6 million to other Papua New Guinea shareholders.
} 
person were approximately K1,100 per year; well above Papua New Guinea's per capita income at the time. ${ }^{32}$

BCL also went to great lengths to encourage the participation of customary owners, and indigenous Bougainvillians more generally, in mining activities. ${ }^{33}$ However, despite BCL's compliance with state law and compensating the customary landowners when they were disrupted, the land acquisition process largely ignored Bougainvillean customary institutions. First, Oliver $(1973,162)$ considers BCL's assessment that land where the mine site was situated was largely inconsequential to Bougainvilleans to be 'tragically misguided' (written well before the development of the crisis). He suggests that all land on the island was owned or identified with one group or another, even if sparsely populated. Oliver $(1973,79)$ also stresses the point that 'the idea of permanent voluntary alienation simply did not exist' and that the current generation considered 'themselves trustees of such land for future generations of kinfolk.' Some customary landowners never accepted BCL's ownership over their land and resources. Furthermore, many customary land owners could never come to terms with receiving what they considered to be such a small portion of the mine's proceeds. As noted by Oliver $(1973,164)$ ' $[\mathrm{t}]$ he principle that the royalties paid on the treasure from one's own land would be used for the Territory as a whole, and not for the land's owners, or even for

\footnotetext{
${ }^{32}$ The Word Bank (2015b) records PNG’s GDP per capita at in 1989 at \$US 874 (\$US923 in 1988); this compares favourably to K1,100 (or \$US1,320). Note this does not include the additional K1.2 million per year paid in salaries and produce purchased from the landowners.

${ }^{33}$ This included assistance with business development; subsidised training and scholarships; a preferential employment policy (and the rapid replacement of expatriate employees); and setting aside 8 per cent of BCL shares for purchase by locals.
} 
Bougainvillians in general, was considered by some Bougainvilleans to be insanely alien' ${ }^{34}$ These tensions were exacerbated as the mine grew in size; it had begun to permanently alter the physical landscape and emit high levels of air and water pollution. For customary landowners, such developments led to growing resentment, and not just from those who had resisted BCL's operations from the beginning. Within this legally pluralistic environment, BCL's property rights were challenged due to divergences between customary (precolonial) and state (postcolonial) notions of ownership rights and what they entail.

Along with altering the physical environment, the mine also had a profound effect on Bougainville's social environment. Thousands of immigrants moved to Panguna and its surrounds to work in the mine and its support industries leading to a sharp increase in ethnic fractionalisation. These workers came from all over the world, but many came from other parts of Papua New Guinea and were pejoratively termed 'redskins' (most Bougainvilleans have a distinctively dark skin pigmentation). With the influx of large numbers of migrants (many of them young single males) social problems also developed, including increased crime and violence. The 'redskins' were blamed which added fuel to an already pre-existing secessionist movement. ${ }^{35}$

The royalty payments themselves also led to social tension and dislocation among landowners. While K1,100 per person per year calculated from Thompson (1991: 91) seems

\footnotetext{
${ }^{34}$ As noted by Nonggoorr (1993), Paul Lapun, the member of the pre-independence House of Assembly representing the Bougainville mine area moved that 20 per cent of royalties to be paid to landowners. His motion was defeated in favour of 5 per cent.

${ }^{35}$ Hermkens $(2007,282)$ highlights the religious and moral elements of the crisis, noting that Francis Ona prayed daily to Our Lady; and that 'the crisis is perceived as something that was necessary to circumvent the decline of sociality and morality...caused by PNG 'redskins' and whites ...leading to a disintegration of Bougainville culture'.
} 
to suggest that the royalties were sufficient to compensate for loss of income (but not necessarily the health, environmental and social damage caused by the mine $)^{36}$, he reports that households living in the lease areas only received compensation of K500 per capita (compared to the average annual return of cash cropping of K807), suggesting that large sums were spent elsewhere. Indeed, the board of the Panguna Landowners' Association (the representative body for mine-lease area customary owners and responsible for the distribution of royalties) was perceived as being corrupt and self serving, especially among the younger generation. ${ }^{37}$ As noted by Lasslet $(2012,4)$, '[v]illagers accused clan leaders of having used their customary position to monopolize compensation, rents and business opportunities'; and it was these perceived injustices that helped Francis Ona and Perpetua Sereo to be elected to the executive of the Panguna Landowners' Association and begin their radical campaign against BCL and the Papua New Guinean state.

While there seems little doubt that the royalties were mal-distributed, Wesley-Smith and Ogan $(1992,256)$ point out the practical difficulties associated with making payments based on customary land rights suggesting that 'the formula for distributing such payments could not possibly take into account the traditional hierarchy of land rights' that included both

\footnotetext{
${ }^{36}$ Thompson $(1991,78)$ notes that while there were significant improvements in public service provision (schools, hospitals and health clinics) there was also respiratory disease, environmental damage (including drinking water contamination), and anti-social behaviour (crime and drunkenness).

${ }^{37}$ Thompson (1991: 82) describes the main grievance as being a:
}

belief that the directors were 'eating the money' of the trust fund themselves; inequitable distribution of the income; the concern that actual expenditure of the trust fund on social amenities was trivial; irregular holdings of meetings and lack of information; and the belief that outsiders were manipulating the board. 
primary rights holders and subsidiary claimants. ${ }^{38}$ Indeed, it is the view of Filer $(1992,115)$ that the 'proximate cause of the rebellion was a process of social disintegration which has also threatened the political integrity of Melanesian communities (even in the pre-colonial period)'. The mine increased economic stratification, distorted property rights, and led to arguments over royalties. This eventually caused the highly decentralized Melanesian institutions to buckle under the pressure with explosive consequences.

\section{DISCUSSION}

This article aims to investigate the role that precolonial institutions play in relation to Papua New Guinea's post colonial natural resource ownership contests, and their consequences in terms of resource management. In order to undertake such a task, it was first necessary to examine Papua New Guinea's precolonial institutions. While it was shown that precolonial institutions were complex, differed from place to place, and are not known with complete certaintly; the evidence does suggest that political authority was remarkably decentralized and land was owned collectively and largely inalienable.

The next step in ascertaining the role of precolonial institutions in Papua New Guinea's resource contests was to investigate colonial land policy; as interventions and antagonisms dating back to this era could be a source of continuing conflict. It was found that colonial administrations largely respected customary property rights, and generally went to considerable lengths to recognise and protect them. Where land was acquired, it was usually deemed to be either uninhabited or voluntarily sold. However, it was found that state sanctioned property rights were nonetheless contested on the grounds of inalienability and

\footnotetext{
${ }^{38}$ Nonggoorr (1993: 440) concludes that [b]ecause customary rules do not identify individual landowners, as no individuals own land, it is often difficult to identify owners and therefore 'payments may be made to the wrong people'.
} 
insufficient authority of the original sellers (to represent all the landowners) throughout the colonial period.

Following an examination of colonial policies and practices relating to land and natural resources, three case studies were examined to illuminate the role of precolonial institutions in relation to natural resource ownership contests; these where the land settlement schemes, the lease-leaseback scheme, and the closure of the Panguna copper mine. While each case is complex and has multiple causes, highly diffused customary political authority and/or notions of inalienability interacting with state institutions played a significant role in each case.

In examining the land settlement schemes, the continued existence of the institution of inalienability is highlighted. It was found that despite the land used for the schemes had already been alienated, and that some landowners were're-compensated' for their loss with the commencement of the scheme, state rights holders had their ownership forcefully contested. In terms of the lease-leaseback scheme, it was found that in addition to rampant state corruption and the presence of exploitative logging companies, the remnants of Papua New Guinea's precolonial institutions also played a role in generating conflict and contests over land ownership. From a review of the cases before Chief Commissioner Numapo (2013) it was found that most involved disputes among customary landowners and that many of these had their roots firmly planted in Papua New Guinea's highly decentralized customary political institutions. The majority of cases involved internal conflict and that some agreements, despite the customary landowner group entering into them voluntary, later unraveled due to sub-groups choosing to 'go it alone' at a later time.

These findings are somewhat less optimistic than Meinzen-Dick and Pradhan (2001) who conclude that legal pluralism can safeguard natural resources for vulnerable groups and improve land management outcomes. In terms of safeguarding the rights of the vulnerable, 
Koczberski and Curry's (2004) account of the land settlement schemes suggests that it is the settlers (those vested with state property rights) who are the more vulnerable. Generally poor, many invested everything they had in the small plots, only to have their property rights forcefully contested by the customary owners. Also, rather than being passive victims predatory companies, customary land owners have proved themselves to be formidable foe; it seems that more than one unsuspecting multinational has fallen prey to the lease-leaseback scheme.

In terms of the case of the closure of Panguna mine, while traditional landholders were compensated monetarily, they were marginalized. It was by reasserting their precolonial land rights that were only partially recognised by the state, that their grievances were heard, albeit with tragic consequences. Much has been written about the Bougainville Crisis and what caused it, and there is no clear consensus in the literature (Regan 1988). For one thing Bougainville had a pre-existing secessionist movement; the mine brought significant environmental, health, social costs; and there were simmering tensions generated by land shortages and social (and class) divisions. However, for some, highly decentralized and fragmented political units and inalienability played a crucial role in the crisis. Nonggoorr (1993: 434) considers that the crisis 'exposed the conflict of values and norms', emphasising differences in customary and state property rights regimes including the notion of inalienability, while Filer (1992: 119) highlights the unravelling of highly decentralized political units. ${ }^{39}$

\footnotetext{
${ }^{39}$ Nonggoorr $(1993,446)$ argues that a lack of central authority leads to 'self-help', 'tribal warfare', and 'physical disruption of investment projects'. In terms of inalienability, Nonggoorr $(1993,437)$ also argues that 'land cannot be transferred freely' because one generation does not have the right to dispose of it. Nonggoorr (1993, 451) goes on to argue that '[e]ven if their land is acquired outright by the State with appropriate payments, landowners still feel that they have some (though undefined) rights to the land and the investments'.
} 
In summary, it is suggested that diffused political authority at the local level coupled with the institution of inalienability, both of which go back to precolonial times, in large part explain each of the natural resource contests investigated. Indeed, more generally, inalienability of land explains why customary landholders renege on leasehold and freehold agreements, even if they (or their ancestors) were willing participants in a leasehold or freehold agreement. ${ }^{40}$ Highly decentralized institutions (even at the village level) mean that even when there is broad agreement a small minority of dissenters (who may have been present and agreed with the original agreement) can halt major projects or overturn sale and leasehold agreements. ${ }^{41}$ The overall consequence of state institutions being overlaid on these institutions is an acute and dysfunctional form of legal pluralism that generates a repeating pattern of property rights contests, a point that has also been elaborated by Filer (2014). ${ }^{42}$

While authors such as MacWilliam $(1988,2013)$ are right to point out that the policies and practices of colonial administration resulted in greater individualization of control of land and that the colonial administration oversaw a period where warfare over land were largely eliminated, it is argued here that customary notions over inalienability and 'self-help' and 'going it alone' largely persisted throughout this period. Indeed, the concept of legal

\footnotetext{
${ }^{40}$ Compensation demands are made over land used for public infrastructure, such as roads and schools that they themselves use (Standish 2001). Inalienability has been a longstanding issue; with Hill, Pernetta, and, Rongap $(1982,357)$ concluding that it 'seems clear that people never feel happy about complete alienation through sale'.

${ }^{41}$ Waiko and Jiregari $(1982,29)$ argue that the definition of the term 'custom' 'includes fighting over resources'. They also provide an account of how a group of Binandere people in Oro Province halted a Saudi and Hong Kong backed logging and timber operation despite most village elders agreeing with it.

${ }^{42}$ Saffu $(1992,337)$ describes this phenomenon:
}

In case after case...landowners made hefty compensation demands, backed their demands with threats of violence if not met by a certain date, did indeed resort to the threatened violence, and, in the overwhelming majority of cases, ended up with some compensation... 
pluralism centres on the possibility that two or more, often conflicting, institutional regimes can persist and coexist indefinitely (Griffiths 1986). While the outward manifestations of these customary institutions may have abated for during a period of peak of state power, they nevertheless remained under the veneer of state authority. Writing well into the post-colonial period Nonggorr $(1993,447)$ considered that most Papua New Guineans 'continue to be regulated by custom' and that 'the government system with central authority has had limited impact on the majority of people'. ${ }^{43}$

In terms of resource management outcomes, competing claims over the same resource (generated by the overlapping of customary and state rights) can lead to it being devalued by both groups involved in the contest leading to less investment, including in its protection. For instance, if small scale settlers cannot secure the proceeds of their labour and investments on their palm oil plots, if agro-forestry companies cannot gain access their leasehold land, and if mine operators cannot count on their mine existing in the near future; their assets, that they rightfully own under the state property rights regime, are largely worthless. ${ }^{44}$ In terms of resource conservation, given their tenuous ownership over natural resources in Papua New Guinea, there is a powerful incentive, even for those who are well intentioned, to exploit them as quickly as possible. Indeed, this analysis suggests that this dysfunctional form of legal pluralism may actually create an adverse section problem, where firms focused on short term exploitative profits are attracted to Papua New Guinea but where firms that are willing

\footnotetext{
${ }^{43}$ More recently, Larcom (2015b) has provided evidence that customary institutions centred on wrongdoing still have widespread acceptability.

${ }^{44}$ In the early post-colonial period, plantation owners were surveyed on why they were not replanting oil palms. Shepherd $(1981,6)$ reports the main reason as uncertainty over security of tenure. He concluded that [c]learly, no plantation is going to invest large sums of money in new plantings if it is likely to be taken over by the traditional landholders before a reasonable return on investment can be secured.'
} 
to take a long term approach are discouraged. Likewise, if customary rights holders cannot secure their pre-existing customary rights, there is also less of an incentive to protect their natural resources from exploitation. Indeed, there is an incentive for customary rights holders to also 'cash-in' their (contested) rights for whatever they can get.

If Papua New Guinea's land and natural resource ownership contests are indeed a consequence of legal pluralism stemming from the persistence of it precolonial institutions, the policy prescriptions to improve the current situation are not readily apparent. While some, such as Lea and Curtin (2011) have called for the roll out of individualized land title across the country, it is unclear whether this would actually see any change in the underlying institutions. Indeed, if the state property rights regime were to move further away from preexisting custom it may simply increase the number and intensity of the natural resource contests.

An alternative path is one where the state, or private companies, bend even further toward pre-existing institutions. One option could see long term use rights exchanged for annual payments rather than going through the pretence of 'selling' them. Such creative leasehold arrangements could see payments based on the profits generated from the land and natural resources in question, which would effectively make customary landowners meaningful partners in all commercial projects on their land. Such an approach would also require a change in the mindset of state property rights holders, who would need to acknowledge the reality deep legal pluralism that is found in Papua New Guinea, and maintain a genuine openness to continual dialogue and renegotiation. ${ }^{45}$ Paradoxically, such a change of approach

\footnotetext{
${ }^{45}$ An example of this could be the practices adopted by New Britain Palm Oil Limited, and I thank an anonymous referee for pointing this out. New Britain Palm Oil Limited (2013:37) state that they are committed to ensuring that 'the community really understand the implications and options of leasing their land' and that [d]iscussions with communities are carried on an ongoing basis'. Furthermore, they state that they do not see
} 
could actually create more certainty for land users rather than less, as it would bring customary and state property rights regimes closer together and therefore reduce the probability of resource ownership contests. Such a move would not be failsafe; as it would still require agreement over the customary ownership of resources, which is often not the case (see Banks 2008 and Filer 2012), but it may still be a step in the right direction.

\section{CONCLUSION}

Papua New Guinea is an extreme outlier in terms of its precolonial institutions. This extremeness makes the transmission channels linking them to natural resource contests readily apparent, while perhaps being obscured in other places. While each case study examined above highlighted the complexity of natural resource conflicts in Papua New Guinea, and their multiple causes, each also provided evidence of the effects of highly decentralized precolonial institutions and notions of inalienability. These precolonial institutions, that remain largely intact, have been overlaid with different and competing state institutions. This is so despite genuine efforts by the state to recognize and incorporate preexisting customary property rights into its own regime.

The existence of multiple property rights over the same resources leads to uncertainty of ownership. This means that in Papua New Guinea state property rights holders are not only subject to sovereign risk but also non-sovereign risk; owing to the very real risk of non-state expropriation. This was evidenced in each of the cases examined; the Panguna mine, the land settlement schemes, and the lease-leaseback scheme. Furthermore, there was also evidence presented (especially in terms of the lease-leaseback scheme) that tenuous ownership creates

requests for lease renegotiations and complaints as 'conflicts' but rather 'part of an ongoing dialogue'. However, they also highlight the problems: 'It is not always easy to determine which individuals are truly representative of the community' and that it 'becomes more complex when we have to consider whether the rights of community minorities should supersede those of the majority'. 
a powerful incentive, even for those with the best of intentions, to exploit natural resources faster than they otherwise would. This may even lead to an adverse selection problem where companies focused on exploiting short term gains are drawn to Papua New Guinea. In a twist to the tragedy of the commons literature, this suggests that too many property rights, as well as too few, can lead to excessive resource exploitation.

One intriguing result from studying Papua New Guinea is that its precolonial institutions show little sign of abating in their importance. Indeed, precolonial institutions may well be growing in strength relative to the state, in an ongoing process of decolonization. If this is the case, and colonial institutions continue to be forcefully dismantled by their inhabitants, it is likely to lead to more property rights contests over land and natural resources. Indeed, the resource rights contests found in Papua New Guinea may be a manifestation of a wider phenomenon of a rebalancing of power between strengthening precolonial institutions and weakening colonial and postcolonial state institutions. 


\section{Bibliography}

Ahlerup, P., and O. Olsson. 2012. The roots of ethnic diversity. Journal of Economic Growth, 17(2), 71-102.

Banks, G. Understanding 'Resource' Conflicts in Papua New Guinea. Asia Pacific Viewpoint, 49(1), 23-34

Biskup, P., B. Jinks, and H.N. Nelson. 1968. A short history of New Guinea. Angus and Robertson: Sydney.

Brandewie, E., 1971. The place of the big man in traditional Hagen society in the central highlands of New Guinea. Ethnology, 10(2), 194-210.

Connell, J. 1978. Taim Bilong Mani: The Evolution of Agriculture in a Solomon Island Society. The Australian National University: Canberra.

Department of Territories. 1969. Internal file titled: Bougainville Copper project-Overall policy and general information (1969/2443). National Archives of Australia (NAA: A452, 1969/2443), http://www.naa.gov.au/. Accessed March 2016.

Eaton, P. 1982. Customary Land Tenure and National Park Development in Papua New Guinea, in L. Morauta, J. Pernetta, and W. Heaney (eds). Monograph 16: Traditional Conservation in Papua New Guinea: Implications for Today, Boroko: Institute of Applied and Social Research, 223-226.

Filer, C. 1990. Diversity of Cultures or Culture of Diversity? in N. Lutkehaus, Sepik Heritage: Tradition and Change in Papua New Guinea, Durham: Carolina Academic Press, $116-128$

Filer, C. 1991. The Bougainville rebellion, the mining industry and the process of social disintegration in Papua New Guinea. Canberra Anthropology, 13(1), 1-39. 
Filer, C. 1992. The Escalation of Disintergration and the Reinvention of Authority, in M.

Sprigs and D. Denoon (eds), The Bougainville Crisis: 1991 Update, Crawford House Press:

Bathurst, 122-140.

Filer, C. 2012. Why green grabs don't work in Papua New Guinea. Journal of Peasant Studies, 39(2), 599-617.

Filer, C. 2014. The Double Movement of Immovable Property Rights in Papua New Guinea, Journal of Pacific History, 49(1), 76-94.

Filer, C., and N. Sekhran. 1998. Loggers, Donors, and Resource Owners. Policy that Works for Forests and People Series no. 2: National Research Institute: Port Moresby, and International Institute for Environment and Development: London.

Fischer, S.R. 2002. A History of the Pacific Islands. Palgrave Macmillan: Hampshire and New York.

Griffiths, J. 1986. What is legal pluralism? The journal of legal pluralism, 18(24), 1-55.

Hasluck, P. 1976. A Time for Building. Melbourne University Press: Melbourne.

Hay, D. 1969. Internal note to Warwick Smith (the Secretary of the Department of External Territories), titled 'Bougainville' dated 6 June 1969. Sourced from Department of Territories internal file titled: Bougainville Copper project - Overall policy and general information (1969/2443). National Archives of Australia (NAA: A452, 1969/2443), http://www.naa.gov.au/. Accessed March 2016.

Hermkens, A-K. 2007. Religion in war and peace: Unravelling Mary's intervention in the Bougainville crisis, Culture and Religion 8(3), 271-289.

Hulme, D. 1982. Land Settlement Schemes in Papua New Guinea: An Overview, Land Reform, Land Settlement and Cooperatives, 1-2, 21-42. 
Jinks, B., P. Biskup, and H. Nelson. 1973. Readings in New Guinea History. Sydney: Angus \& Robertson

Kambuou, R. N. 1996. Papua New Guinea: Country Report to the FAO International Technical Conference on Plant and Genetic Resources, Leipzig. Available at: http://www.fao.org/fileadmin/templates/agphome/documents/PGR/SoW1/asia/PAPUANEW. pdf [Accessed January 2016]

Kirch, P.V. 1997. The Lapita peoples: Ancestors of the Oceanic world. The Peoples of SouthEast Asia and the Pacific. Blackwell: Cambridge, MA.

Knoll, A.J., and H.J. Hiery, eds. 2010. The German Colonial Experience: Select Documents on German Rule in Africa, China, and the Pacific 1884-1914. Maryland: University Press of America.

Koczberski, G., and G. Curry. 2004. Divided communities and contested landscapes: Mobility, development and shifting identities in migrant destination sites in Papua New Guinea. Asia Pacific Viewpoint, 45(3), 357-371.

Larcom, S. 2013. Taking customary law seriously: a case of legal re-ordering in Kieta. The Journal of Legal Pluralism, 45(2), 190-208.

Larcom, S. 2015a. Legal Dissonance: The Interaction of Criminal Law and Customary Law in Papua New Guinea. Oxford: Berghahn Books

Larcom, S.. 2015b. Internalizing Legal Norms: An Investigation into the Legitimacy of Payback Killings in the New Guinea Islands. Law \& Society Review, 49(1), 179-208.

Lasslett, K. 2012. State Crime by Proxy Australia and the Bougainville Conflict. British Journal of Criminology, 52, 705-723. 
Lasslett, K., P. Green, and Dawid Stańczak. 2014. The barbarism of indifference: Sabotage, resistance and state-corporate crime. Theoretical Criminology, 19(4) 514-533.

Laurance, W. F., T. Kakul, M. Tom, R. Wahya, and S.G. Laurance. 2012. Defeating the 'resource curse. Key priorities for conserving Papua New Guinea's native forests. Biological Conservation, 151(1), 35-40.

Lawrence, P. 1969. The State versus Stateless Societies in Papua and New Guinea, in P.J. Brown (ed.), The Fashion of Law in New Guinea. Sydney: Butterworths, pp. 15-37.

Lea, D., and T. Curtin. 2011. Land Law and Economic Development in Papua New Guinea. Newcastle: Cambridge Scholars.

Lewis, M.P., G.F. Simons, and C.D. Fennig (eds.). 2014. Ethnologue: Languages of the World, Seventeenth edition. Dallas, Texas: SIL International. Online version: http://www.ethnologue.com.

MacWilliam, S. 1988. Smallholdings, land law and the politics of land tenure in Papua New Guinea, The Journal of Peasant Studies, 16:1, 77-109.

MacWilliam, S. 2013. Securing Village Life: Development in Late Colonial Papua New Guinea, ANU E Press: Canberra.

Matsuda, M.K. 2012. Pacific Worlds: a History of Seas, Peoples, and Cultures. Cambridge University Press: New York.

May, R.J. 2004. State and society in Papua New Guinea: the first twenty-five years. Canberra: Anu E Press.

McEwen, J. 1969. Letter to Mr Adams, President of the Planters' Association of New Guinea dated 13 May 1969. Sourced from Department of Territories internal file titled: Bougainville Copper project - Overall policy and general information (1969/2443). National 
Archives of Australia (NAA: A452, 1969/2443), http://www.naa.gov.au/. Accessed March 2016.

Meinzen-Dick, R.S., and R. Pradhan. 2001. Implications of legal pluralism for natural resource management. IDS Bulletin, 32(4), 10-17.

Mihalic, F. 1989. The Jacaranda Dictionary and Grammar of Melanesian Pidgin. Milton, Qld: The Jacaranda Press.

Morauta, L., J. Pernetta, and W. Heaney (eds). 1982. Monograph 16: Traditional Conservation in Papua New Guinea: Implications for Today, Boroko: Institute of Applied and Social Research.

Müller, H-P., C.K. Marti, E.S. Schiedt, and B. Arpagaus. 2000. Atlas Vorkolonialer Gesellschaften: Kulturelles Erbe Und Sozialstrukturen Der Staaten Afrikas, Asiens Und Melanesiens, Berlin: Reimer. available at: <http://www.worlddevelopment.uzh.ch/index.html>, accessed October 2014. Murdock, G.P. 1969. Ethnographic Atlas, Pittsburgh, PA: University of Pittsburgh Press. Narokobi, B. 1996. Law and Custom in Melanesia, Point Series No.12. Goroka: Institute of Pacific Studies of the University of the South Pacific and Melanesian Institute for Pastoral and Socio-Economic Service.

New Britain Palm Oil Limited. 2013. Sustainability Report 2012/13. Available at http://www.nbpol.com.pg/wp-content/uploads/downloads/2014/04/New-Britain-Palm-OilLimited-NBPOL-Sustainability-Report-2012-13.pdf. Accessed March 2016.

Newman, A.P.J. 1969. Bougainville Copper Project: Statement Delivered by the Acting Assistant Administrator (Economic Affairs), Territory of Papua and New Guinea. Sourced from Department of Territories internal file titled: Bougainville Copper project - Overall 
policy and general information (1969/2443). National Archives of Australia (NAA: A452, 1969/2443), http://www.naa.gov.au/. Accessed March 2016.

Nonggoorr, J. 1993. Resolving Conflicts in Customary Law and Western Law in Natural Resource Developments in Papua New Guinea, UNSW Law Journal, 16(2), 433-457.

Numapo, J. 2013. Commission of Inquiry into the Special Agriculture and Business Lease (SABL): Final Report (From Chief Commissioner). Port Moresby. Available at: http://www.coi.gov.pg/documents/COI\%20SABL/Numapo\%20SABL\%20Final\%20Report.p df. [Accessed December 2015]

O’Neill, P. Undated. Statement by the Prime Minister Hon. Peter O'Neill CMG MP on the Report on the Commission of Inquiry into Special Agriculture and Business Leases. Press Release: Port Moresby.

http://www.coi.gov.pg/documents/COI\%20SABL/PM\%20Statement\%20COI\%20SABL\%20 Final\%20Report.pdf [Accessed December 2015].

Oliver, D. 1973. Bougainville: A Personal History. Honolulu: The University Press of Hawaii.

Regan, A.J. 1998. Causes and course of the Bougainville conflict. The Journal of Pacific History, 33(3), 269-285.

Rowley, C.D. 1958. The Australians in German New Guinea, 1914-1921. Melbourne: Melbourne University Press.

Roullier, C., R.Kambouo, J. Paofa, D. McKey, \& V. Lebot. 2013. On the origin of sweet potato (Ipomoea batatas (L.) Lam.) genetic diversity in New Guinea, a secondary centre of diversity. Heredity, 110(6), 594-604.

Sack, P., and D. Clark. 1979. German New Guinea: The Annual Reports. Australian National University Press: Canberra. 
Saffu, Y. 1992. The Bougainville Crisis and Politics in Papua New Guinea, The Contemporary Pacific, 4(2), 325-343.

Shepherd, A. 1981. Plantations in Papua New Guinea: Copra, Tea and Rubber Estates, in M. Walter, What do we do about Plantations?, Institute of Applied Social and Economic Research: Boroko, 5-11.

Standish, B. 2001. Papua New Guinea in 1999-2000, Journal of Pacific History, 36(3), 285298.

Strathern, M. (1995). Women in Between: Female Roles in a Male World: Mount Hagen, New Guinea. Lanham: Rowman \& Letterfield: (First published in 1972).

Summerhayes, G. R., M. Leavesley, A. Fairbairn, H. Mandui, J. Field, A. Ford, and R. Fullagar. 2010. Human adaptation and plant use in highland New Guinea 49,000 to 44,000 years ago. Science, 330(6000), 78-81.

Thompson, H. 1991. The economic causes and consequences of the Bougainville crisis, Resources Policy, 17(1), 69-85.

Thompson, H., and S. MacWilliam. 1992. The political economy of Papua New Guinea: critical essays. Journal of Contemporary Asia Publishers.

Wesley-Smith, T., and E. Ogan. 1992. Copper, class, and crisis: changing relations of production in Bougainville. The Contemporary Pacific, 4(2), 245-267.

West, F.. 1968. Hubert Murray: The Australian Pro-Consul. Melbourne: Oxford University Press.

Wiako, J., and K. Jiregari. 1982. Conservation in Papua New Guinea: Custom and Tradition, in L. Morauta, J. Pernetta, and W. Heaney (eds). Monograph 16: Traditional Conservation in Papua New Guinea: Implications for Today, Boroko: Institute of Applied and Social Research, 21-39. 
World Bank. 2015a. Papua New Guinea Overview, Washington D.C. from http://www.worldbank.org/en/country/png/overview\#1 [Accessed May 2015].

World Bank. 2015b. 'World Development Indicators Database'. Washington D.C.

http://data.worldbank.org/country/papua-new-guinea [Accessed January 2016]

Zhang, D., G. Rossel, A. Kriegner, and R. Hijmans. 2004. AFLP assessment of diversity in sweetpotato from Latin America and the Pacific region: Its implications on the dispersal of the crop. Genetic Resources and Crop Evolution, 51(2), 115-120. 